\title{
Anatomia de lesões foliares causadas pelo vírus da Mancha Clorótica do Clerodendrum, transmitido pelo ácaro Brevipalpus phoenicis em diferentes espécies
}

\author{
Renata Takassugui Gomes ${ }^{1}$, Elliot Watanabe Kitajima ${ }^{1}$, Francisco André Osamu Tanaka ${ }^{1}$, João Paulo Rodrigues \\ Marques $^{2}$, Beatriz Appezzato-da-Glória²
}

\begin{abstract}
${ }^{1}$ Escola Superior de Agricultura “Luiz de Queiroz”, Universidade de São Paulo, 13418-900, Piracicaba, SP; Fitopatologia e Nematologia; ${ }^{2}$ Escola Superior de Agricultura “Luiz de Queiroz”, Universidade de São Paulo, 13418-900, Piracicaba, SP; Ciências Biológicas. Parte da dissertação de mestrado da primeira autora
\end{abstract}

Autor para correspondência: Elliot Watanabe Kitajima (ewkitaji@esalq.usp.br)

Data de chegada: 17/02/2009. Aceito para publicação em: 26/06/2010.

1645

\section{RESUMO}

Gomes, R.T.; Kitajima, E.W.; Tanaka, F.A.O.; Marques, J.P.R.; Appezzato-da-Glória, B. Anatomia de lesões foliares causadas pelo vírus da Mancha Clorótica do Clerodendrum, transmitido pelo ácaro Brevipalpus phoenicis em diferentes espécies Summa Phytopathologica, v.36, n.4, p.291-297, 2010.

O gênero botânico Clerodendrum pertence à família Lamiaceae e compreende várias espécies ornamentais, Manchas cloróticas e necróticas em folhas de coração-sangrento foram observadas pela primeira vez em um jardim de Piracicaba, SP, associadas à infestação com Brevipalpus phoenicis (Acari: Tenuipalpidae). Exames de secções de tecidos das lesões foliares ao microscópio eletrônico revelaram ocorrência de efeitos citopáticos do tipo nuclear e concluiu-se que os sintomas eram causados por um vírus transmitido por Brevipalpus (VTB), o qual foi designado de mancha clorótica de Clerodendrum (Clerodendrum Chlorotic Spot Virus- ClCSV). O ClCSV é transmitido mecanicamente de coração-sangrento para coração-sangrento. Em ensaios preliminares foi transmitido por B. phoenicis e mecanicamente para várias outras plantas, além da ocorrência de sua disseminação natural por este ácaro para outras espécies. Visando complementar a caracterização do ClCSV foram feitos estudos sobre alterações anatômicas em folhas de plantas infectadas pelo ClCSV. Foram examinadas secções histológicas de folhas sadias e infectadas pelo ClCSV de C. x speciosum e de outras hospedeiras como Hibiscus schizopetalus, Salvia leucantha, Malvaviscus arboreus e Annona muricata. Constatou-se que o ClCSV causa alterações celulares semelhantes nas diferentes hospedeiras e os sintomas causados por este vírus são similares aos causados por outros vírus transmitidos por Brevipalpus como o vírus da leprose dos citros citoplasmático (Citrus Lepros Virus Cytoplasmic- CiLV-C) e nuclear (Citrus Leprosis Virus Nuclear- CiLV-N), mancha anular do cafeeiro (Coffee Ringspot VirusCoRSV), mancha anular de Solanum violaefolium (Solanum violaefolium Ringspot Virus- SvRSV) e "Orchid Fleck Vírus" (OFV), representadas por hipertrofia e hiperplasia frequentemente acompanhadas de necrose nos tecidos do parênquima paliçádico e lacunoso.

Palavras-chave adicionais: ClCSV, Brevipalpus phoenicis, Clerodendrum x specious, Histopatologia

\section{ABSTRACT}

Gomes, R.T.; Kitajima, E.W.; Tanaka, F.A.O.; Marques, J.P.R.; Appezzato-da-Glória, B.Anatomy of leaf lesions caused by Clerodendrum Chlorotic Spot Virus (ClCSV) transmitted by the mite Brevipalpus phoenicis in different host species. Summa Phytopathologica, v.36, n.4, p.291$297,2010$.

The botanical genus Clerodendrum belongs to the family Lamiaceae and includes several ornamental species. Necrotic and chlorotic spots on leaves of bleeding heart were observed for the first time in a residential garden from Piracicaba Municipality, São Paulo State, Brazil, associated with an infestation by the flat mite Brevipalpus phoenicis (Acari: Tenuipalpidae). Tissue section analysis of the leaf lesions under transmission electron microscope showed characteristic cytopathic effects of the nuclear type, indicating that the symptoms were caused by a Brevipalpus-transmitted virus (BTV), named Clerodendrum Chlorotic Spot Virus (ClCSV). This virus was shown to be transmitted mechanically and by B. phoenicis to several plant species. In order to complete ClCSV characterization, anatomical changes in the leaf lesions of ClCSV-infected leaves were evaluated. Histological sections of healthy, control leaves and leaf lesions of ClCSV-infected plants of C. x speciosum, Hibiscus schizopetalus, Salvia leucantha, Malvaviscus arboreus and Annona muricata were analyzed. ClCSV infection resulted in similar tissue alterations caused by other BTV as Citrus Leprosies Virus Cytoplasmic (CiLV-C) and Nuclear (CiLV-N), Coffee Ringspot Virus (CoRSV), Solanum violaefolium Ringspot Virus (SvRSV) and Orchid Fleck Virus (OFV). Such symptoms consisted of hypertrophy and hyperplasia frequently followed by necrosis in palisade and spongy parenchyma tissues.

Keywords: ClCSV; Brevipalpus phoenicis, Clerodendrum x speciosum, Histopathology 
Clerodendrum é um gênero botânico pertencente à família Lamiaceae e compreende várias espécies de importância hortícola e são utilizadas na culinária, medicina, indústria farmacêutica e cosmética, além de espécies ornamentais, muito cultivadas em jardins residenciais e parques, cobrindo muros e cercas (18). Essa família apresenta distribuição cosmopolita, com cerca de 300 gêneros e aproximadamente 7500 espécies. No Brasil, ocorrem cerca de 350 espécies distribuídas em 26 gêneros (23).

Plantas de coração-sangrento (Clerodendrum x speciosum [Tiejism. \& Binn.]) que apresentavam folhas com manchas cloróticas e necróticas foram observadas pela primeira vez em um jardim residencial de Piracicaba, SP, associadas à infestação com ácaros identificados como Brevipalpus phoenicis (Geijskes) (Acari: Tenuipalpidae) (14). As lesões foliares foram reproduzidas após transferência de ácaros de plantas com sintomas para plantas sadias e exames de secções de tecidos das lesões foliares ao microscópio eletrônico revelaram a ocorrência de efeitos citopáticos do tipo nuclear dos vírus transmitidos por ácaros Brevipalpus (VTB) (12, 14). Concluiu-se então que os sintomas eram causados por um vírus transmitido pelo acáro Brevipalpus (VTB), e o vírus designado como mancha clorótica de Clerodendrum (Clerodendrum chlorotic spot virus- ClCSV).

O gênero Brevipalpus compreende mais de 300 espécies, sendo B. phoenicis (Geijskes), B. californicus (Banks) e B. obovatus Donnadieu as espécies reconhecidas como vetores de fitoviroses, tais como a da leprose do citros, mancha anular do cafeeiro, "Orchid fleck", entre outros. As três principais espécies de Brevipalpus foram relatadas em 928 espécies de plantas em 513 gêneros distribuídas em 139 familías e estão distribuídas em toda região tropical e subtropical do planeta (4).

O ClCSV encontra-se bastante disseminado no Estado de São Paulo, tendo sido constatado também em outras unidades da Federação como Distrito Federal, Santa Catarina, Pará e Amazonas. É transmitido por B. phoenicis e mecanicamente de coraçãosangrento para coração-sangrento e para várias outras espécies de plantas. Em Chenopodium quinoa Willd. e C. amaranticolor Coste \& Reyn. a inoculação mecânica resulta em lesões locais que se tornam sistêmicas se as plantas forem mantidas em temperaturas altas. Como o título do vírus em tecidos infectados sistemicamente é alto, isto proporcionou a possibilidade de purificar o vírus, tendose produzido anti-soro específico (14). Pode-se obter parte do seu genoma, com o qual foram desenhados "primers" para detecção molecular do vírus. Ensaios moleculares (17) e sorológicos (9) preliminares indicam que ClCSV seria distinto de dois outros VTB do tipo nuclear, respectivamente "Orchid fleck vírus" (OFV) e mancha anular do cafeeiro (Coffee ringspot vírus- CoRSV). OFV teve seu genoma inteiramente seqüenciado tendo similaridades em sua organização com rhabdovirus e um novo gênero Dichorhabdovirus foi proposto para acomodá-lo, por diferir de outros membros da família pelo seu genoma bipartido (15) e tanto CoRSV como ClCSV possivelmente integram este gênero. ClCSV foi detectado nos tecidos do vetor B. phoenicis e assim como outros VTB do tipo nuclear, também visualizados no vetor (OFV, CiLVN, CoRSV e mancha clorótica de Solanum violaefolium-SvCSV) possivelmente replicar-se-ia no ácaro vetor (13).

O objetivo deste trabalho foi verificar como os tecidos das diferentes plantas hospedeiras reagem à infecção pelo ClCSV a fim de complementar a caracterização deste vírus e comparar estas alterações histológicas com aquelas causadas por outros vírus transmitidas por Brevipalpus $(2,7,16,19,20)$.

\section{MATERIAL E MÉTODOS}

Para a realização das análises morfo-anatômicas dos tecidos de Clerodendrum x speciosum, Hibiscus schizopetalus Hook.f., Salvia leucantha Cav., Malvaviscus arboreus Cav. e Annona muricata L. utilizaram-se amostras de folhas sadias e contendo lesões, coletadas em jardins do parque do campus da Escola Superior de Agricultura Luiz de Queiroz, Piracicaba, SP. A presença do ClCSV nestas amostras foi confirmada paralelamente por RT-PCR usando "primers" específicos (17).

Os sintomas foliares foram registrados digitalmente e a seguir, fragmentos das lesões foram fixados em solução de Karnovsky (11). Para melhor penetração da solução fixadora, as amostras foram colocadas em um dessecador e o ar retirado com uma bomba de vácuo $(0,1 \mathrm{~mm} \mathrm{Hg})$ por $10 \mathrm{~min}$. Após a fixação, as amostras foram desidratadas em série de concentração crescente de etanol e infiltradas em hidroxietil-metacrilato (Leica Historesin). Os blocos obtidos foram seccionados a $5 \mu \mathrm{m}$ de espessura em micrótomo rotatório Leica RM 2045.

As secções foram montadas em lâminas de vidro e posteriormente coradas com: azul de Toluidina (22) para as análises histológicas usuais, Sudan Black B para detectar substâncias lipídicas (21), cloreto férrico para verificar compostos de natureza fenólica (10), cloreto de zinco iodado para detectar amido, vermelho de rutênio para a detecção de compostos de natureza péctica (3) e xylidine Ponceau para detecção de compostos protéicos (5).

Depois de coradas, as lâminas histológicas foram montadas em resina sintética "Entellan" e as imagens foram capturadas com câmera de vídeo Leica DC 300F acoplada ao microscópio Leica DMLD.

\section{RESULTADOS E DISCUSSÃO}

\section{Folhas Sadias}

\section{Clerodendrum $x$ speciosum (Fig. 1 A, B)}

O limbo foliar de coração-sangrento é composto por parênquima clorofiliano de uma camada de células em paliçada e cinco a seis camadas de parênquima lacunoso constituídas por células de contorno arredondado e tamanho uniforme. O espaço intercelular é conspícuo em todo o mesofilo. A epiderme é formada por uma camada de células de contorno elíptico achatado e cutícula espessa na face adaxial. $\mathrm{Na}$ face abaxial, a epiderme possui células de tamanho reduzido em relação à da face adaxial. Adicionalmente, na epiderme abaxial, nota-se presença de tricomas tectores. A nervura central é composta por feixe vascular do tipo colateral em "V", circundados por oito camadas de células parenquimáticas na face adaxial e quatro camadas na abaxial. Nota-se a ocorrência de duas camadas de células do colênquima tangenciando a epiderme da face adaxial.

\section{Annona muricata (Fig. 1 C)}

O mesófilo da folha de A. muricata é constituído por uma camada de parênquima paliçádico de células alongadas, justapostas e com citoplasma denso. Compõe o parênquima lacunoso, células de forma e tamanho variados, desde isodiamétrico a braciforme, em cinco a seis camadas. As células braciformes estão presentes tangenciando a epiderme adaxial. Os espaços intercelulares do parênquima lacunoso são conspícuos. A epiderme adaxial possui células de forma retangular ou quadrada, tendo a parede anticlinal alinhada verticalmente ao limbo. O tamanho das células é homogêneo. A epiderme adaxial é constituída 
por células de formas variadas e desuniformes no tamanho, menores que as da adaxial.

\section{Hibiscus schizopetalus (Fig. 1 D)}

As folhas da $H$. schizopetalus são constituídas por parênquima clorofiliano de arranjo denso, não podendo ser observado espaços intercelulares conspícuos. O parênquima paliçádico possui células alongadas, estreitas e justapostas. O parênquima lacunoso acha-se formado por células de forma variável, arranjadas mais densamente. Circundando o feixe vascular, notam-se duas camadas de bainha do feixe. A epiderme adaxial possui células, de forma variável, maiores em relação à adaxial. Intercaladas às células epidérmicas, notam-se idioblastos de mucilagem. A ocorrência de tricomas glandulares em ambas as faces é destacada pela formação de concavidades no limbo foliar, alojando o tricoma e nivelando a porção apical do tricoma ao nível da epiderme.

\section{Malvaviscus arboreus (Fig. 1 E)}

O mesofilo da $M$. arboreuss é formado por parênquima paliçádico ocupando mais da metade do volume do mesofilo. As células são alongadas, justapostas com acúmulo de substância densa no vacúolo.
No parênquima lacunoso encontram-se células de forma variável, com espaços intercelulares de volume reduzido. Frequentemente, o parênquima clorofiliano é entremeado por idioblastos de cristais (drusas) conspícuos, ocupando a largura total do mesofilo. A epiderme é constituída por uma camada de células de tamanho variável, maiores na epiderme adaxial. Na face adaxial notam-se tricomas glandulares inseridas no nível da epiderme.

\section{Salvia leucantha (Fig. 1 F)}

O limbo da folha da salvia-branca é constituído por parênquima clorifiliano de células com contorno e forma bem definidos. No parênquima paliçádico encontram-se células alongadas de forma retangular, em duas camadas, justapostas, sendo maiores as células da camada superior. Logo abaixo, nota-se uma camada de células coletoras. O parênquima paliçádico possui células isodiamétricas intercaladas a células alongadas, que se organizam de forma compacta. Os espaços intercelulares são formados pelas células isodiamétricas. A epiderme adaxial é formada por células de forma achatada elipsoidal. O tamanho é variado. A epiderme abaxial é formado por células de tamanhos variados e, em algumas regiões, duas menores, intercaladas com uma célula maior, formando um padrão de organização.
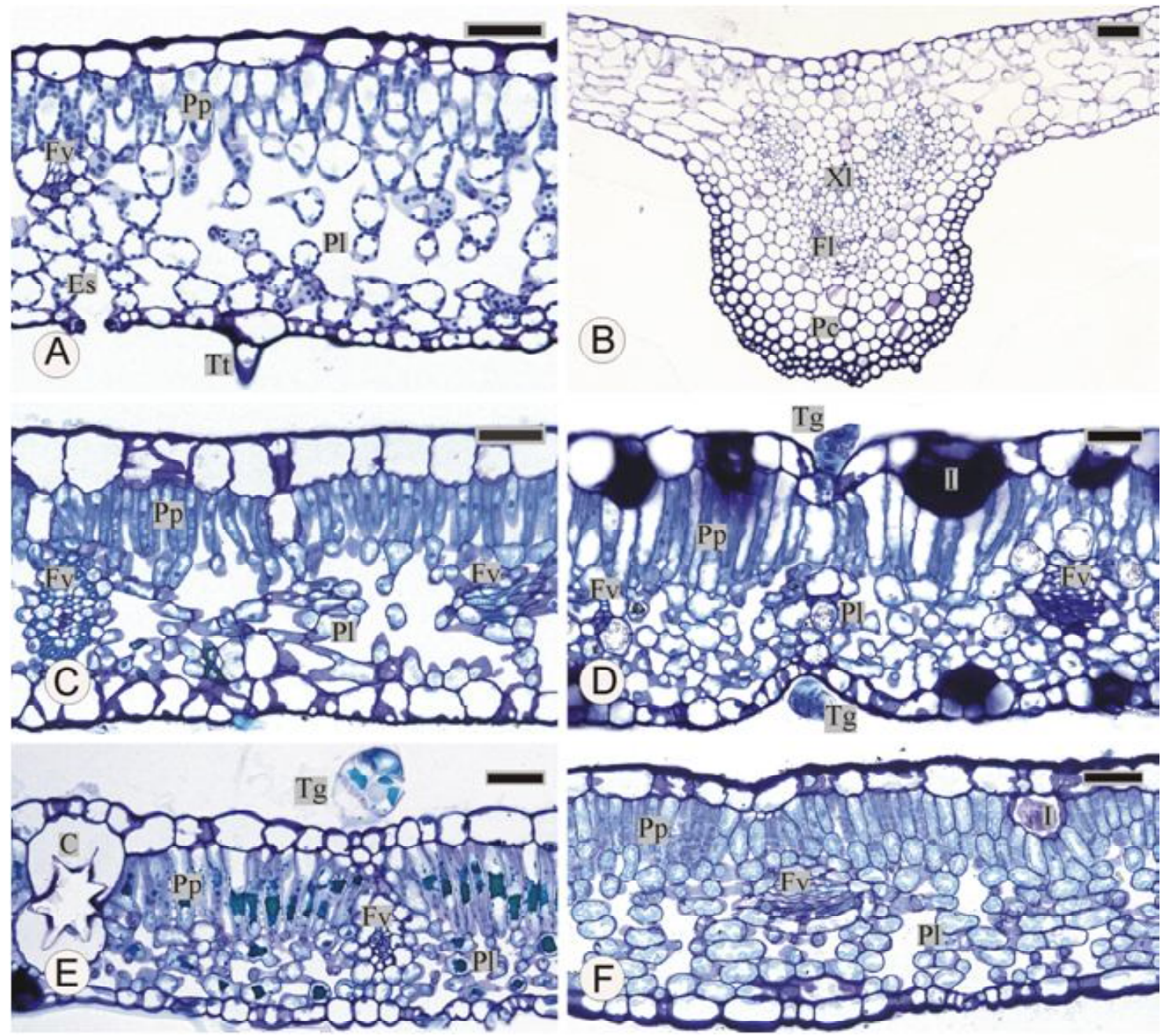

Figura 1. Cortes transversais de folhas sadias coradas com azul de toluidina. A. Lâmina foliar de Clerodendrum $x$ speciosum. B. Nervura central de Clerodendrum x speciosum. C. Lâmina foliar de Annona muricata. D. Lâmina foliar de Hibiscus schizopetalus. E. Lâmina foliar de Malvaviscus arboreus. F. Lâmina foliar de Salvia leucantha (Barras $50 \mu \mathrm{m}$ ). Fl- floema; Fv- faixa vascular; .I- idioblasto; Pc- parênquima cortical; Pl- parênquima lacunoso; Ppparênquima paliçádico; Tg- tricoma glândular; Xl- xilema 
Folhas de plantas infectadas pelo CICSV (Figs. 2, 3 e 4)

As lesões cloróticas representam uma fase inicial da infecção foliar pelo ClCSV. Na análise anatômica dessas lesões nota-se a ocorrência de alterações no conteúdo celular da epiderme, do parênquima paliçádico e do parênquima lacunoso. Nas células da epiderme nota-se a presença de conteúdo granular (Figura 2 C). Além da alteração do conteúdo das células do parênquima paliçádico, ocorrem também alterações nos cloroplastos do parênquima paliçádico e lacunoso (Figura $2 \mathrm{~A}-\mathrm{C}$ ). Chagas (2) ao analisar tecidos infectados com CoRSV observou alterações como a diminuição das dimensões dos cloroplastos nas células do parênquima paliçádico e nas células do parênquima lacunoso contíguas às do parênquima paliçádico. Observa-se nas lesões cloróticas a ocorrência de hipertrofia nas células do parênquima lacunoso em regiões próximas onde ocorrem células plasmolisadas (Figura 2 DE). Marques (20) descreveu em células infectados com CILV-N células do mesofilo plasmolisadas, além do aumento da espessura do limbo foliar devido a hipertrofia e a atividade hiperplásica das células do parênquima lacunoso. Em folhas infectadas por OFV e por SvRSV também observou-se a ocorrência de hipertrofia nas células do parênquima lacunoso. Kubo (16) notara células hipertrofiadas com o conteúdo vazio e parede celular pouco densa em plantas infectadas com o OFV enquanto Ferreira (7) relata células do parênquima lacunoso hipertrofiadas em folhas infectadas com o SvRSV.

Em lesões causadas pelo CiLV-C em folhas de laranjeiras, Gomes et al. (8) analisaram as células hipertrofiadas e em hiperplasia através de microscopia eletrônica e constataram que raramente notam-se evidências de invasão das mesmas pelo vírus, indicadas pela ausência de presumíveis partículas virais e do viroplasma. Segundo Marques $(19,20)$, a presença de células hipertrofiadas e em hiperplasia no halo intermediário das lesões causadas por CiLV-C ou CILV-N poderiam em conjunto com o halo necrótico promover uma barreira para que o vírus permanecesse confinado à lesão.

As lesões necróticas representam uma fase mais avançada da doença, posterior a etapa onde ocorrem manchas cloróticas. Através da análise anatômica destas lesões pode-se observar o conteúdo celular alterado da epiderme, parênquima paliçádico (Figura 3 A-D) e lacunoso (Figura 3 B-E). Nota-se também o colapso da epiderme e a deformação das células do parênquima paliçádico e lacunoso (Figura $3 \mathrm{C}$ e D).

Além dessas alterações, houve a ocorrência de hipertrofia e hiperplasia das células do parênquima lacunoso (Figuras 2D e 3 D). Marques (20) observou uma acentuada da hipertrofia celular nas lesões avançadas, causadas tanto por CiLV-C como por CiLV-N. Observouse também a ocorrência de lise da célula do parênquima lacunoso e na região da nervura central (Figura $3 \mathrm{E}$ e F), provavelmente após a ocorrência de hipertrofia dessas células.

Num estágio mais avançado das lesões necróticas observaram-se depressões resultantes da obliteração de células da epiderme (Figura 4 A e E) e a presença de conteúdo granular além de células totalmente necrosadas (Figura 4A-E). Marques (19) também observou a ocorrência de depressões isoladas na superfície do limbo foliar de plantas com sintomas de CiLV-C, resultantes da intensa obliteração das células da epiderme e do parênquima lacunoso. Chagas (2) efetuou cortes em lesões de folhas infectadas com CoRSV de aspecto necrótico e observou que as células da epiderme superior mostravam-se deformadas. Ocorria também a deformação e necrose do parênquima paliçádico, que se apresentava adensado, não sendo mais possível verificar as estruturas celulares como cloroplastos ou núcleo.

A hipertrofia das células do parênquima paliçádico e lacunoso é

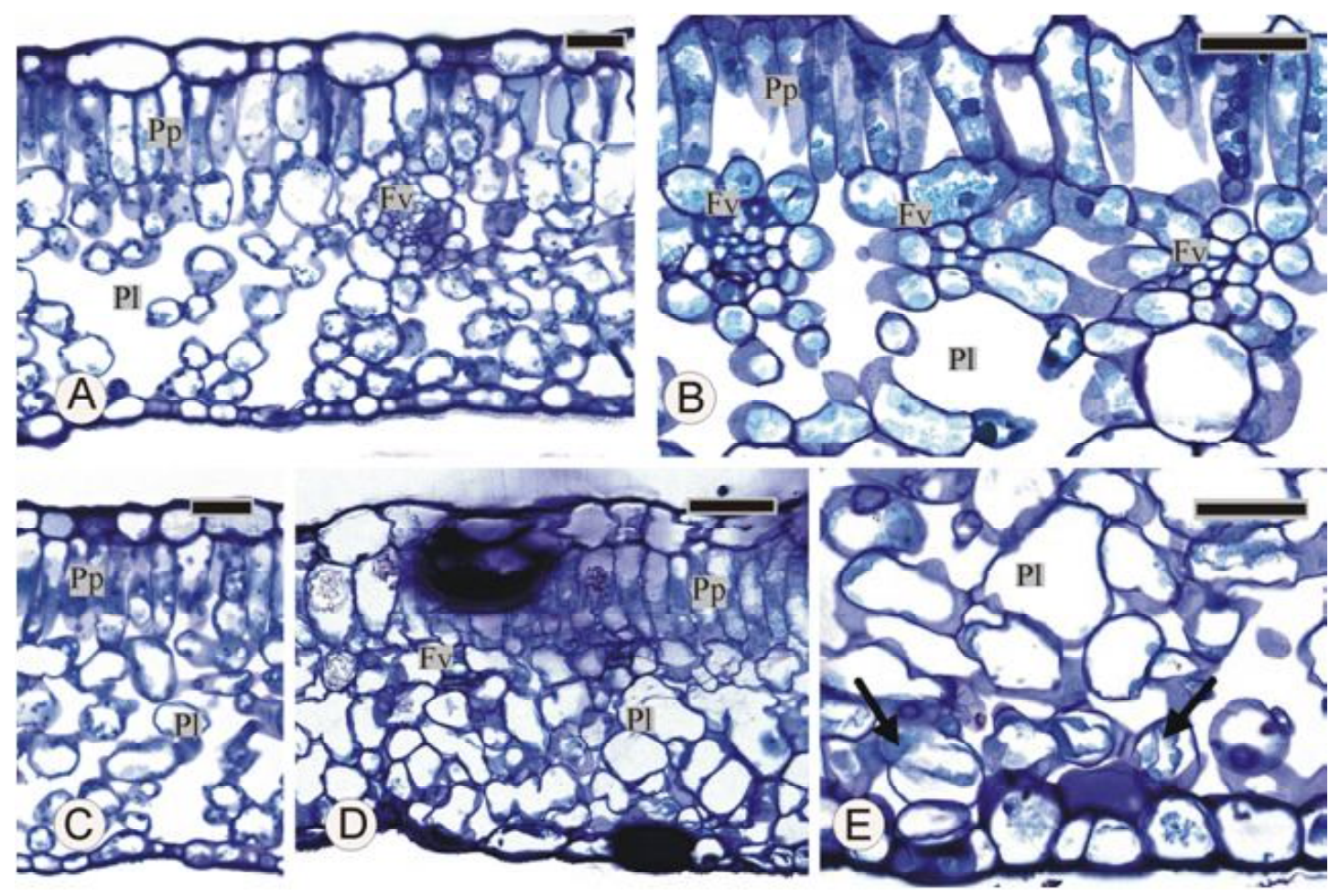

Figura 2. Cortes transversais da fase inicial das lesões foliares causadas pelo ClCSV corados com azul de toluidina. A e C. Lâmina foliar de Clerodendron x speciosum (Barra $30 \mu \mathrm{m}$ ). B. Lâmina foliar de Annona muricata (Barra $30 \mu \mathrm{m})$. D e E. Lâmina foliar de Hibiscus schizopetalus (Barras $50 \mu \mathrm{m}$ e $30 \mu \mathrm{m})$. Em A nota-se hiperplasia celular no parênquima paliçádico acima do feixe vascular (seta). Observar o conteúdo granular das células epidérmicas, os cloroplastos alterados em B (setas) e as células hipertrofiadas e plasmolisadas (setas em E). Fv- faixa vascular; .I- idioblasto; Pl- parênquima lacunoso; Ppparênquima paliçádico; $\mathrm{Tg}$ - tricoma glândular 

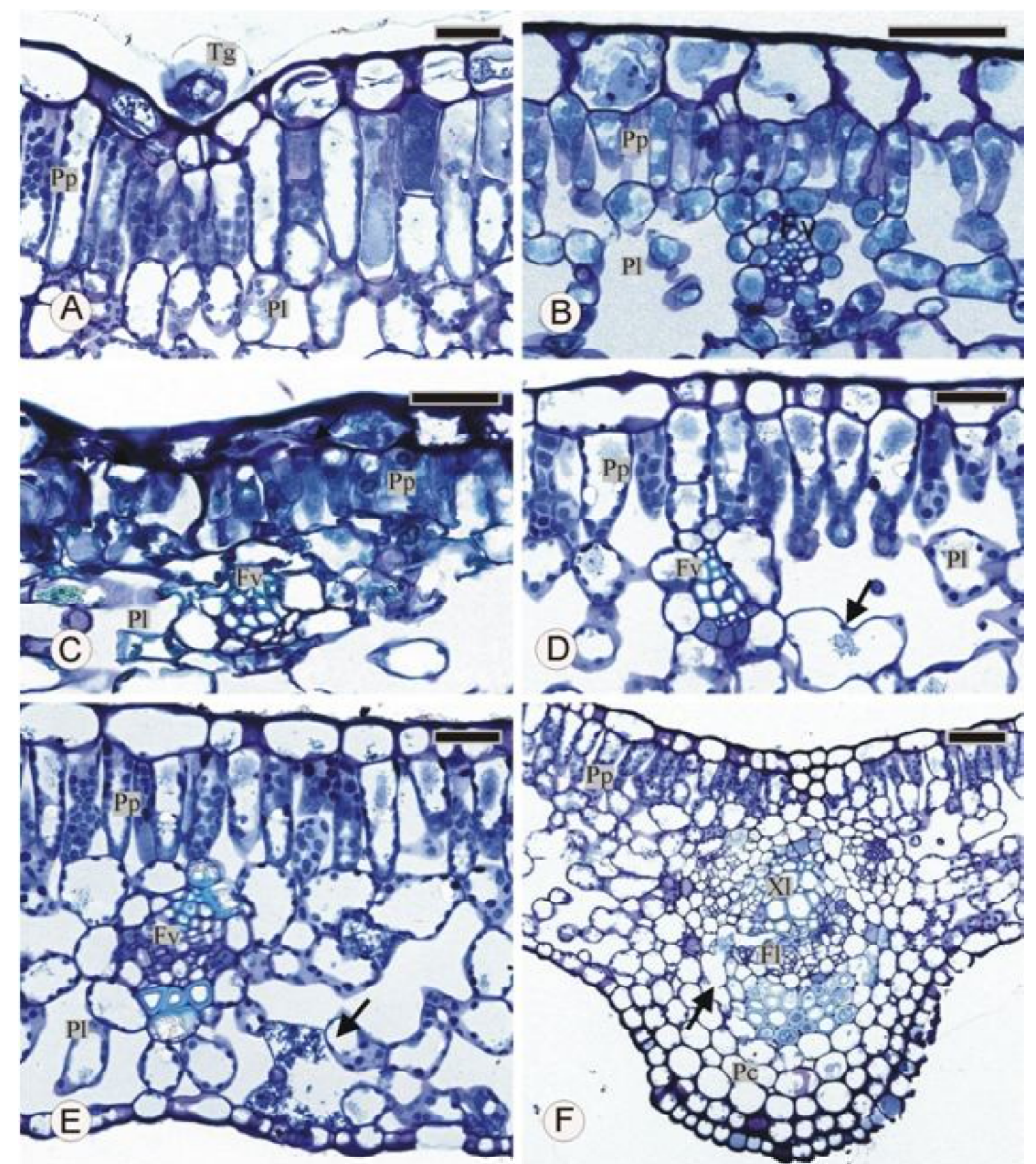

Figura 3. Cortes transversais da fase avançada das lesões foliares corados com azul de toluidina. A, D, E e F. Lâmina foliar de Clerodendron $x$ speciosum (A, D e E Barras $30 \mu \mathrm{m}$ e F Barra $50 \mu \mathrm{m}$ ). B. Lâmina foliar de Annona muricata (Barra $50 \mu \mathrm{m}$ ). C. Lâmina foliar de Salvia leucantha (Barra $30 \mu \mathrm{m})$. Observar conteúdo celular alterado da epiderme, do parênquima paliçádico (A-D) e do parênquima lacunoso (B-E). C. Colapso da epiderme (setas) e deformação das células do parênquima paliçádico e lacunoso. D. Hipertrofia das céulas do parênquima lacunoso (seta). E. Lise da célula do parênquima lacunoso (seta). F. Lise celular na região da nervura central (seta). Fl- floema; Fv- faixa vascular; .I- idioblasto; Pl- parênquima lacunoso; Pp- parênquima paliçádico; Tg- tricoma glândular; Xl- xilema.

marcante, verificando-se em algumas delas lise celular (Figura 4 A e B). Há eventualmente colapso nos elementos do feixe vascular (Figura $4 \mathrm{C}$ e D). De acordo com Esau (6), a necrose no parênquima lacunoso causa o colapso das nervuras menores, ocorrendo inicialmente necrose das células da bainha nos feixes vasculares seguida da necrose do floema imaturo, alcançando por fim o xilema e o floema diferenciados. Marques (20) também relatou que a lise celular e a concomitante necrose do parênquima paliçádico em folhas de laranjeiras, infectadas pelo CiLV-N atingiram feixes vasculares, levando ao colapso dos mesmos. Segundo este autor, o colapso dos feixes vasculares poderia limitar o deslocamento do CiLV-N a longas distâncias, enquanto a necrose celular interferiria no deslocamento a curta distância, célula-àcélula.

De uma maneira geral, as alterações aqui relatadas em tecidos das lesões causadas pelo ClCSV em diferentes hospedeiras tem um padrão similar principalmente na região do parênquima. Ocorrem grupos de 

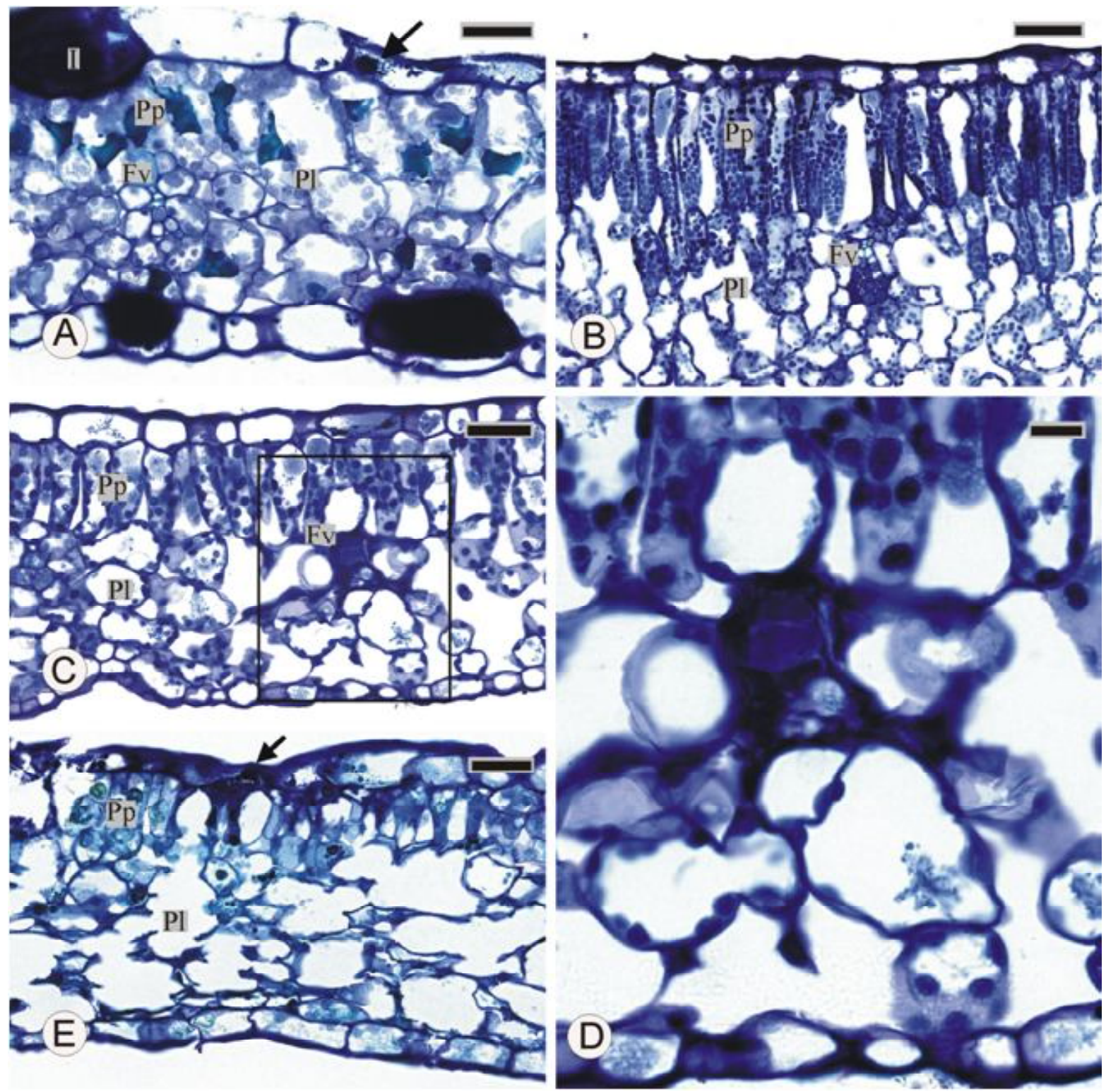

Figura 4. Cortes transversais da fase avançada das lesões foliares corados com azul de toluidina. A. Lâmina foliar de Malvaviscus arboreus (Barra 30 um). B e C. Lâmina foliar de Clerodendron x speciosum (Barras $30 \mu \mathrm{m}$ ). D. Região em destaque em C (Barra $10 \mu \mathrm{m}$ ). E. Lâmina foliar de Salvia leucantha (Barra $30 \mu \mathrm{m}$ ). Observar depressões na epiderme (setas) em A e E . Em B verifica-se ocorrência de grupos de células hiperplásticas no parênquima paliçádico (seta). Hipertrofia das células do parênquima paliçádico e lacunoso em A e. C-D (setas). Em E notam-se alterações no feixe vascular e no conteúdo das células do parênquima paliçádico e lacunoso com intensa lise das células do parênquima paliçádico e lacunoso. Em todas figuras observamse alterações no conteúdo celular. Fv- faixa vascular; .Pl- parênquima lacunoso; Pp- parênquima paliçádico.

células necrosadas, hipertrofia em algumas células do parênquima lacunoso e eventual hiperplasia no parênquima paliçádico. Partes da epiderme acham-se necrosadas e colapsadas. A região vascular pode também estar afetada, com indícios de necrose. Estes efeitos citopáticos devem representar o efeito da invasão e replicação do ClCSV e também dos mecanismos de reação da planta para impedir a expansão da lesão. Aparentemente na maioria dos casos de infecção por VTB, sejam do tipo nuclear ou citoplasmático, a infecção termina por ficar limitada na lesão e os vírus não se tornam sistêmicos.

O movimento célula à célula condicionada pela proteína de movimento permite a expansão inicial da lesão, mas os mecanismos de defesa da planta terminam por restringir esta expansão. Há algum mecanismo ainda não compreendido que dificulta a infecção dos tecidos da região vascular e como conseqüência a translocação do vírus a grandes distâncias via floema. Em hospedeiras como Chenopodium quinoa e $C$. amaranticolor, caso as plantas infectadas sejam mantidas a temperaturas mais altas $\left(28-30^{\circ} \mathrm{C}\right)$, alguns VTB do tipo nuclear como OFV, CoRSV e ClCSV tornam-se sistêmicos $(1,14,15)$. Neste caso os mecanismos que dificultam a infecção dos tecidos vasculares seriam superados e os vírus atingiriam as células condutoras do floema e se dispersariam para outras regiões da planta.

Concluindo, as alterações notadas nas plantas aqui analisadas (coração-sangrento, H. schizopetalus, graviola, Malvaviscus arboreus e salvia branca) seguem no geral os efeitos histopatológicos relatados para outros VTB, do tipo nuclear ou citoplasmático, envolvendo hipertrofia e hiperplasia de alguns tecidos, necrose de parte do tecido foliar e colapso da região vascular. Este processo deve estar relacionado ao fato de a infecção por VTB usualmente ficar localizado, sem se 
tornar sistêmico, indicando um tipo de resposta semelhante dos tecidos à infecção procurando evitar a disseminação da infecção, independentemente da espécie da planta infetada.

\section{Agradecimentos}

Este trabalho contou com apoio financeiro da FAPESP (2000/ 11805-0 e 2008/52691-9).

\section{REFERÊNCIAS BIBLIOGRÁFICAS}

1. Boari, A.J.; Kubo, K.S.; Alcântara, B.K.; Kitajima, E.W. Purificação do vírus da mancha clorótica do Clerodendrum. In: Congresso Paulista de Fitopatologia, 29, 2006, Botucatu. Anais... Botucatú: Grupo Paulista de Fitopatologia, 2006. 1 CD-ROM.

2. Chagas, C.M. Mancha anular do cafeeiro: transmissibilidade, identificação do vetor e aspectos anátomo-patológicos. 1978. 131 p. Tese (Doutorado em Ciências Biológicas- Botânica) - Instituto de Biociências, Universidade de São Paulo, São Paulo, 1978.

3. Chamberlain, C.J. Methods in plant histology. Chicago: The University of Chicago Press, 1932. 416 p.

4. Childers, C.C.; Rodrigues, J.C.V.; Welbourn, W.C. Host plants of Brevipalpus californicus, B. obovatus, and B. phoenicis (Acari: Tenuipalpidae) and their potential involvement in the spread of viral diseases vectored by these mites. Experimental and Applied Acarology, Dordrecht , v. 30, p. 29-105, 2003.

5. Cortelazzo, A.L. Caracterização celular e bioquímica de sementes. Campinas: UNICAMP, 2007. 13 p.

6. Esau, K. Anatomy of plant virus infections. Annual Review of Phytopathology, Palo Alto, v. 5, p. 45-76, 1967.

7. Ferreira, P.T.O., Locali-Fabris, E.C., Freitas-Astúa, J., AntonioliLuizoni, R., Gomes, R.T., Machado, M.A. \& Kitajima, E.W. Caracterização de um vírus baciliforme isolado de Solanum violaefolium transmitido pelos ácaros Brevipalpus phoenicis e Brevipalpus obovatus (Acari: Tenuipalpidae). Summa Phytopathologica, Botucatu, v. 33, p. 264-269, 2007.

8. Gomes, R.T.; Marques, J.P.R.; Salsaroli, R.; Appezzato-da-Glória, B.; Kitajima, E.W. Análise ultra-estrutural de lesões foliares causada pela leprose do citros - tipo citoplasmático - e distribuição das células infectadas na lesão. In: Mostra Acadêmica, 12; Encontro de Iniciação Científica, 2., 2004, Piracicaba. Resumo expandido. Piracicaba: UNIMEP, 2004. (1 CD-ROM).

9. Gomes, R.T. Caracterização biológica e molecular do vírus da mancha clorótica de Clerodendrum (Clerodendrum Chlorotic Spot Virus- CLCSV). 2009. 55 p. Dissertação (Mestrado em Fitopatologia) - Escola Superior de Agricultura "Luiz de Queiroz”, Universidade de São Paulo, Piracicaba, São Paulo, 2009.

10. Johansen, D.A. Plant microtechnique. New York: McGrawHill, 1940. 523 p.
11. Karnovsky, M.J. A formaldehyde-glutaraldehyde fixative of high osmolality for use in electron microscopy. Journal of Cell Biology, New York, v. 27, p. 137-138, 1965.

12. Kitajima, EW, Rodrigues, JCV \& Freitas-Astúa, J. An annotated list of ornamentals naturally found infected by Brevipalpus mitetransmitted viruses. Scientia Agricola, Piracicaba, vol. 67, p. 348-371, 2010.

13. Kitajima, E. W. Electron microscopic evidence that nuclear type of Brevipalpus transmitted viruses multiplies in the mite vector. In: Congresso Sociedade Brasileira de Microscopia e Microanálise, 21. 2007, Búzios, RJ. Resumos, Rio de Janeiro, RJ: Sociedade Brasileira de Microscopia e Microanálise, 2007. v. 1. p. 1-2. (1 CD ROM).

14. Kitajima, E.W.; Kubo, K.S.; Ferreira, P.T.O.; Alcântara, B.K.; Boari, A.J.; Gomes, R.T.; Freitas-Astúa, J.; Rezende, J.A.M.; Morais, J.M.; Salaroli, R.B. Chlorotic spots on Clerodendrum, a disease caused by a nuclear type of Brevipalpus (Acari: Tenuipalpidae) transmitted virus. Scientia Agricola, Piracicaba, v. 65, n. 1, p. 36-49, 2008

15. Kondo, H.; Maeda, T.; Shirako, Y.; Tamada, T. Orchid fleck virus is a rhabdovirus with an unusual bipartite genome. Journal of General Virology, Reading, v. 87, p. 2413-2421, 2006.

16. Kubo, K. Detecção e variabilidade do gene de nucleocapsídeo de isolados de diferentes regiões geográficas do vírus da mancha das orquídeas ("Orquid fleck virus" - OFV). 2006. 101 p. Dissertação (Mestrado em Fitopatologia) - Escola Superior de Agricultura "Luiz de Queiroz", Universidade de São Paulo, Piracicaba, São Paulo, 2006.

17. Kubo, K.S., Freitas-Astúa, J., \& Kitajima, E.W. Detecção do Clerodendrum chlorotic spot virus in plants and its mite vector. Summa Phytopathologica, vol. 34 (sup1.), p. S97. 2008.

18. Lorenzi, H.; Souza, H.M. Plantas ornamentais do Brasil: arbustivas, herbáceas e trepadeiras. 3. ed. Nova Odessa: Instituto Plantarum, 2001. 1088 p.

19. Marques, J.P.R.; Freitas-Astúa, J.; Kitajima, E.W.; Appezzato-daGlória, B. Lesões foliares e de ramos de laranjeira-doce causadas pela leprose dos citros. Pesquisa Agropecuária Brasileira, Brasília, v. 42, n. 11, p. 1531-1536. 2007.

20. Marques, JPR, Kitajima, EW, Freitas-Astúa, J, Appezzato-daGlória, B. Comparative morpho-anatomical studies of the lesions caused by citrus leprosis virus on sweet orange. Anais da Academia Brasileira de Ciências, Rio de Janeiro, vol. 82, n. 2, p. 501-511. 2010.

21. Pearse, A.G.E. Histochemistry, theoretical and applied. 3rd ed. London: Churchill,1968. v. 1, 998p.

22. Sakai, W.S. Simple method for differential staining of paraffin embedded plant material using toluidine blue O. Stain Technology, Baltimore, v. 48, n. 5, p.247 249, 1973.

23. Souza, V.C.; Lorenzi, H. Botânica sistemática: guia ilustrado para identificação das famílias de angiospermas da flora brasileira, baseado em APG II. Nova Odessa: Instituto Plantarum, 2005. 640 p. 